\title{
Efeito de culturas starter sobre a qualidade microbiológica de salames tipo Italiano*
}

\author{
FABIANA LOPES AGOSTINI
}

Guiomar Pedro Bergmann (Orientador - UFRGS)

Banca: Cesar Augusto Avancini (UFRGS), Erna Vogt de Jong (UFRGS), Luciana Ruschel dos Santos (UPF)

No presente trabalho, foram estudados os efeitos da cultura starter comercial, Staphylococcus xylosus DD-34 e Pediococcus pentosaceus PC-1, na qualidade microbiológica de salames tipo italiano, fabricados experimentalmente. Aplicouse 4 diferentes tratamentos: I- tratamento controle, sem a cultura starter; II- com cultura starter; III- com inoculação de Staphylococcus aureus, cepa ATCC 6538, numa dose infectante de 8,0x106 UFC/mL e sem cultura starter; IV-inoculação da mesma dose infectante de $S$. aureus e cultura starter. Foram maturados em sala climatizada, durante 25 dias, em temperatura de $18-20^{\circ} \mathrm{C}$ e umidade relativa do ar de $85-90 \%$. Foi realizada a contagem de estafilococos coagulase-positiva, mesófilos aeróbios e coliformes totais, nos dias $0,2,7,15$ e 25 e determinação do $\mathrm{pH}$, nos dias 0,2,3,7,15 e 25. Os resultados demonstraram que o crescimento de $S$. aureus nos salames com adição da cultura starter foi significativamente menor que nos salames sem cultura starter, a partir do $2^{\circ} \mathrm{dia}$, sendo que no $25^{\circ}$ dia havia um número de $S$. aureus de $3,16 \log _{10} \mathrm{UFC} / \mathrm{g}$, no tratamento sem starter, versus $1,99 \log _{10} \mathrm{UFC} / \mathrm{g}$, no tratamento com starter. Na contagem de mesófilos aeróbios não observou-se diferença significativa entre os tratamentos, do $2^{\circ}$ até o $25^{\circ}$ dia (média total 7,61 $\log _{10} \mathrm{UFC} / \mathrm{g}$ ). A contagem de coliformes totais declinou a partir do $2^{\circ}$ dia nos tratamentos com e sem starter até o final da maturação. Quanto à determinação de $\mathrm{pH}$, nos salames com cultura starter, houve um declínio mais rápido no valor de $\mathrm{pH}$ a partir do $2^{\circ}$ dia, de 6,0 para 5,5; enquanto que nos salames controle, a queda do $\mathrm{pH}$ iniciou no $3^{\circ}$ dia, de 6,0 para 5,6. A partir do $7^{\circ}$ dia, o $\mathrm{pH}$ manteve-se constante, apresentando valores estatisticamente iguais entre os tratamentos, com uma média final de 4,88. Concluiu-se que o uso da cultura starter, Staphylococcus xylosus DD-34 e Pediococcus pentosaceus PC-1, exerceu influência sobre a diminuição da população de $S$. aureus ATCC 6538.

Descritores: salame tipo italiano, microbiologia, Staphylococcus aureus, bactéria acidolática, pH, cultura starter.

* Dissertação de Mestrado n. 359 (Especialidade: Inspeção e Tecnologia de Produtos de Origem Animal).73 f. Programa de Pós-graduação em Ciências Veterinárias da Faculdade de Veterinária - UFRGS. CORRESPONDÊNCIA: F.L. Agostini [flagostini@yahoo.com.br]. 


\title{
Effects of starter cultures on microbiological conditions of italian dry salami $* *$
}

\author{
FABIANA LOPES AGOSTINI
}

\author{
Guiomar Pedro Bergmann (Adviser - UFRGS)
}

Committee: Cesar Augusto Avancini (UFRGS), Erna Vogt de Jong (UFRGS), Luciana Ruschel dos Santos (UPF)

The effects of commercial starter culture: Staphylococcus xylosus DD-34 and Pediococcus pentosaceus PC-1, in bacterial inhibition of italian dry salami experimentally fabricated, were assessed. Four treatments were done: I- control group, without starter; II- with starter; III- no starter and $8.0 \times 10^{6} \mathrm{CFU} / \mathrm{mL}$ of Staphylococcus aureus (ATCC 6538); IVstarter and $8.0 \times 10^{6} \mathrm{CFU} / \mathrm{mL}$ of $S$. aureus (ATCC 6538). The salamis rippened for 25 days under $18-20^{\circ} \mathrm{C}$, and relative humidity of $85-90 \%$. Coagulase-positive staphylococci, aerobic mesophilic and total coliforms counts were performed on days $0,2,7,15$ and 25, while pH evaluated on days $0,2,3,7,15$ and 25. Results showed that $S$. aureus growth in salamis with starter was significantly lower than in control group, during all the experiment period: $1.99 \log _{10} \mathrm{CFU} / \mathrm{g} \times 3.16 \log _{10} \mathrm{CFU} / \mathrm{g}$, respectively, in the $25^{\text {th }}$ day. Mesophilic populations didn't show significant diferences in all treatments until the $25^{\text {th }}$ day (total mean was $7.61 \log _{10} \mathrm{CFU} / \mathrm{g}$ ). Total coliform counts were lowered from the $2^{\text {nd }}$ until the $25^{\text {th }}$ day, independently of the treatment used. $\mathrm{pH}$ dropped faster in samples containing starter culture since the $2^{\text {nd }}$ day, while those samples from control group showed the beggining of $\mathrm{pH}$ drop only on the $3^{\text {rd }}$ day. However, from the $7^{\text {th }}$ day until the end of the analysis period, the treatments had equal $\mathrm{pH}$ values. It was concluded that the starter culture used, Staphylococcus xylosus DD-34 and Pediococcus pentosaceus PC-1, was able to lower S. aureus, ATCC 6538.

Key words: salami, microbiology, Staphylococcus aureus, lactic acid bacteria, $\mathrm{pH}$, starter culture.

\footnotetext{
**Master's Thesis no. 359 (Field: Food Safety and Inspection). 73 p. Graduate Program in Veterinary Sciences, Faculdade de VeterináriaUFRGS. CORRESPONDENCE: F.L. Agostini [flagostini@yahoo.com.br].
} 